\title{
Status of phosphorus in the rain forest ecosystem of Mt. Pangasugan, Leyte, Philippines
}

\author{
Janice P. Susaya ${ }^{1}$ and Victor B. Asio ${ }^{12}$ \\ ${ }^{\prime}$ Institute for Tropical Ecology, Leyte State University, Baybay, Leyte, Philippines: \\ ${ }^{2}$ Department of Agronomy and Soil Science, Leyte State University, Baybay, \\ Leyte, Philippines
}

\begin{abstract}
Susaya, J. P. and V. B. Asio. 2005. Status of phosphorus in the rain forest ecosystem of Mt. Pangasugan, Leyte, Philippines. Ann. Trop. Res. 27 (2): 69-80

Phosphorus $(\mathrm{P})$ is generally considered to be the most limiting mineral nutrient in tropical soils. This study was conducted to determine the amounts of $P$ in various components of the rainforest ecosystem. Composite samples of rocks, soil, stream sediments, stream water, rainwater, leaves of dominant vegetation, forest litter, wood and moss were randomly collected from a portion of the rain forest in Mt. Pangasugan, Leyte, Philippincs. Samples were analyzed for their total $P$ contents.

Findings revealed that $P$ concentration varied substantially in the various ecosystem components evaluated. Higher $\mathrm{P}$ concentrations were found in the biosystem components particularly in the leaves of the vegetation than in the geosystem components. The $P$ concentrations decreased in the following order: fresh leaves $>$ moss $>$ litter $>$ soil $>$ sediment $>$ rock $>$ wood $>$ stream water $>$ rainwater. Trace amount of $\mathrm{P}$ is brought into the ecosystem by rain. On the other hand, considerable amounts of $P$ are found in the stream water and stream sediments which represent $P$ losses from the rainforest ecosystem. This substantial loss of $P$ is attributed to human disturbance in the forest ecosystem.
\end{abstract}

Keywords: phosphorus status, rain forest ecosystem, nutrient cycling

Correspondence: J. Susaya, Present Address: Institute of Tropical Ecology, Leyte State University, Baybay, Leyte, Philippines 6521-A Tel. No.(053)335-2652 


\section{INTRODUCTION}

Phosphorus $(\mathrm{P})$ is considered as the most limiting mineral nutrient in tropical areas especially in rain forest ecosystems (Vitousek, 1984). This is generally attributed to the low $\mathrm{P}$ content of most soil-forming rocks and to the various chemical precipitation reactions in the soil, which render it unavailable to plants (Sanchez, 1976; Jordan, 1985).

Ecological studies in the past have shown that native vegetation is able to cope with low available $P$ in the soil by adaptive mechanisms such as efficient P cycling, mycorrhizal association and low demand for phosphorus (Gisi, 1990; Marschner, 1995). In some terrestrial ecosystems, significant amount of $\mathrm{P}$ also comes from rainwater.

The rain forest of Mt. Pangasugan is part of the remaining small patch of forest (less than 5\%) in Leyte which has been declared recently as one of the biodiversity hotspots of the Philippines (Asio and Bande, 2005). Previous geo-ecological works conducted in the area comfirmed that $\mathrm{P}$ is the most limiting mineral nutrient in the soil due to the low $\mathrm{P}$ content of the parent rocks and the acidic and highly weathered nature of the soil (Jahn and Asio, 1998). However, native plants thrive well, even forming a multi-layered canopy, indicating that sufficient amount of $\mathrm{P}$ is probably being cycled from the soil to the vegetation and back.

Until now, little information exists regarding the status and distribution of $\mathrm{P}$ in the various components of this rainforest ecosystem. Specifically, very few research has yet been done that quantified the amounts of $P$ present in the surface soil, subsoil, rocks, litter, vegetation, stream water, stream sediments and rainwater. For these reasons, this study was conducted.

\section{MATERIALS AND METHODS.}

\section{Description of the study area}

The study site is a portion (about $0.5 \mathrm{ha}$ ) of the secondary forest in the lower slope of Mt. Pangasugan at about $100 \mathrm{~m}$ above sea level in Baybay, Leyte, Philippines (Figure 1). The site extends from the middle slope down to the Calbigaa stream. The geology of the site is dominated by andesitic and 


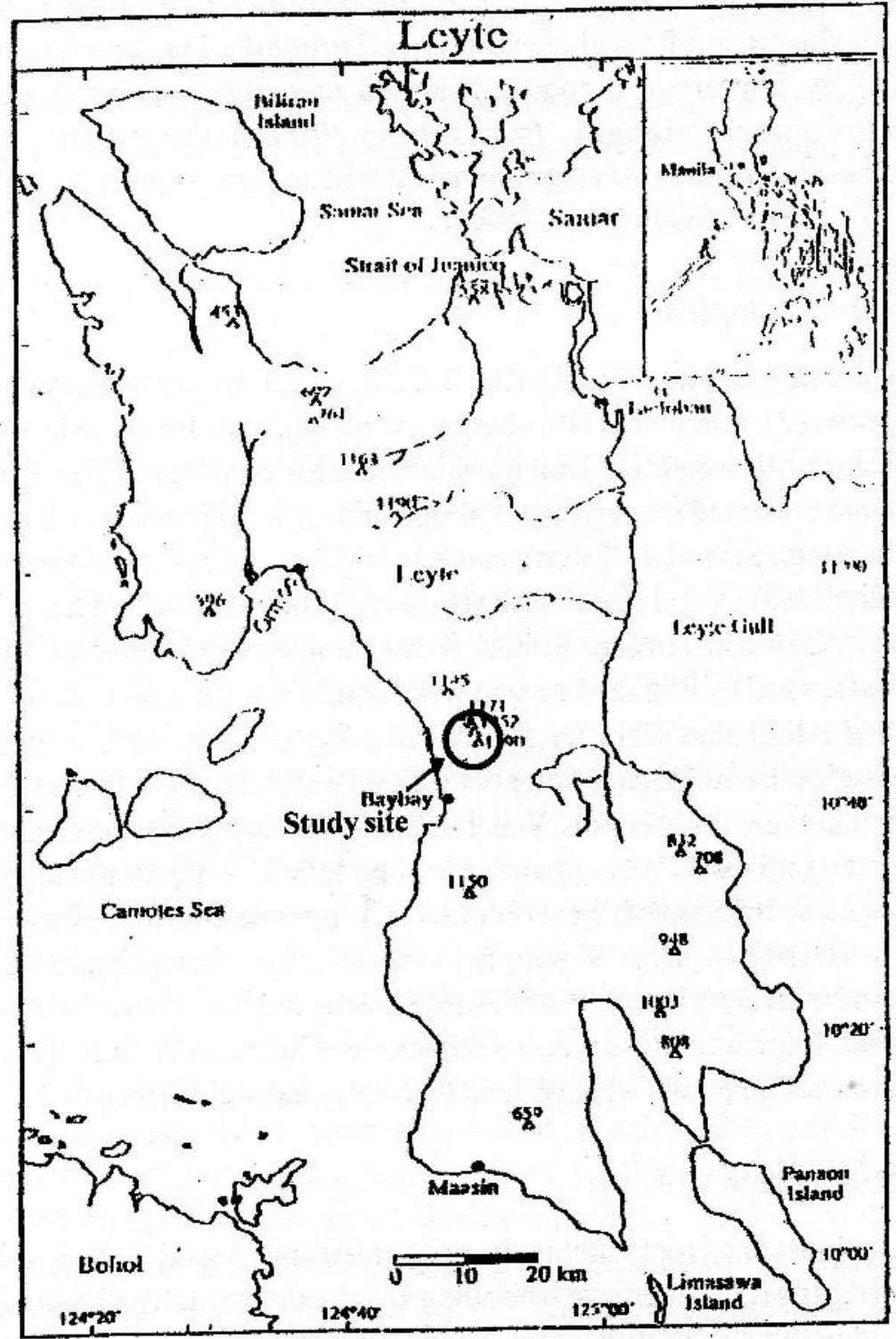

Figure 1. Location of study site in Leyte, Philippines 
basaltic pyroclastic rocks of Pliocene to Pleistocene age. The soil is a highly weathered, clayey, acidic soil classified as Hapludult. The vegetation is dominated by Dipterocarp species like Pterocarpus indicus (narra), Pentacme contorta (lauan), Parashorea plicata (bagtikan), and Dracontomelon dao (dao). Average annual rainfall and temperature are 2,800 $\mathrm{mm}$ and $27^{\circ} \mathrm{C}$, respectively (Asio, 1996).

\section{Collection of samples}

Composite samples of rocks (3), soil (8), wood (6), fresh leaves (8), litter (8), moss (2), rainwater (10), stream water (10), and stream sediments (4) were randomly collected from the study site for total P analysis. Rock samples were collected from typical basaltic and andesitic boulders using a geologic hammer. Surface $(0-20 \mathrm{~cm})$ and subsurface $(20-40 \mathrm{~cm})$ soil samples were collected using a soil auger. Sediment samples were collected from the streambed of Calbigaa stream. Stream water samples were collected from various portions of Calbigaa stream at weekly interval for 3 months using acid-washed 1-liter plastic bottles. Rainwater samples were collected using an improvised collection setup ( 1 liter bottle fitted with funnel and filter paper) after every rain event for 3 months. Water samples were analyzed immediately or refrigerated until use. Fully expanded healthy leaves of the dominant tree species (Dipterocarp species) were collected. Composite litter samples were taken from each point where soil samples were collected. This included small twigs and the undecomposed litter to ensure that no significant loss of $P$ has yet occurred. Representative wood samples were taken from fallen trees. Moss and moss-like plants were collected on rock and soil surfaces.

\section{Cherkical analysis}

Soil, sediment and rock samples were air-dried and ground. Soil samples were allowed to pass a 2 -mm sieve while the ground sediment and rock samples were sieved using a $0.25 \mathrm{~mm}$ sieve. Then they were analyzed for total $\mathrm{P}$ content by following the boiling concentrated $\mathrm{HCl}$ method of Schlichting $e t$ al., (1995). Plant tissue samples were wiped with clean moist tissue paper, dried in an oven at $70^{\circ} \mathrm{C}$, ground in a Wiley mill and ashed in a furnace at $500^{\circ} \mathrm{C}$ - They were then analyzed for total P content using the dry ashing 
procedure (PCARR, 1980). Rainwater and stream water samples were analyzed following the vanadomolybdophosphoric acid colorimetric method (PCARR, 1980). Samples were prepared for transmittance reading in a spectrophotometer (Spectronic 20D+ Milton Roy) at wavelength of $880 \mathrm{~nm}$.

\section{RESULTS AND DISCUSSION}

\section{Geosystem components}

Results revealed that the soil had the highest amount of total P (544.07 $\mathrm{ppm}$ ) among the geosystem components (Fig. 3). This value is close to the mean total $P$ value of the rock which was $471.55 \mathrm{ppm}$. These results agree with the findings of an earlier geo-ecological study in Mt. Pangasugan (Asio, 1996) and with the findings of Lindsay (1987) as cited by Kou (1996) showing that total P concentration in soil ranges from 200 to $500 \mathrm{mgkg}^{-1}$. Data also showed that $14.98 \mathrm{ppm} P$ is contributed into the ecosystem by rain, the lowest among the ecosystem components. Losses of $\mathrm{P}$ from the forest ecosystem are shown by the $P$ content of the stream water $(26.17 \mathrm{ppm})$ and the sediments (512.23 ppm).

Igneous rocks in Mt. Pangasugan are naturally low in $\mathrm{P}$ which agrees with the report of Wedepohl (1969) that the average $\mathrm{P}_{2} \mathrm{O}_{2}$ content of igneous rocks is only $0.18 \%$. As a result, soils in the study area which were developed from these rocks are P-deficient (Zikeli et al., 2000). The fact that soils get most of their nutrients from their parent rocks explains why the total $P$ values for the rock and soil were close to each other. But the higher total $P$ of the soil compared to that of the rock suggests external $\mathrm{P}$ input to the soil probably from litter decomposition, rain and other sources.

Considerable $\mathrm{P}$ addition to the soil comes from decomposed plant and animal tissues. The decomposition of plant and animal biomass by macro and microdecomposers releases mineral nutrients back to the soil. The decomposition rate in typical rainforests is generally high due to high moisture and temperature conditions resulting in the fast release and uptake of $\mathrm{P}$ by plants (Sanchez, 1976).

Small amounts of $\mathrm{P}$ input coming from the rain add up to the soil's $\mathrm{P}$ 
content. The P content of rainwater is believed to have come from ashes and dusts generated by burning activities in the nearby community since no atmospheric fixation for P occurs (Day et al., 1987).

Heavy rains cause soil erosion and leaching of nutrients and thus result in the transport of trace amounts of $\mathrm{P}$ from upper to lower slopes of the forest and usually end up in the water channel. In the case of the study site, run-off water flows towards the Calbigaa stream, thereby contributing to the total $\mathrm{P}$ in the stream water. This could partly explain the P content of the stream water which averaged $26.17 \mathrm{ppm}$. Another reason could be the contribution of rock weathering and litter decomposition in the stream.

Considerable amount of total P (512.23 ppm) was likewise found in the sediment samples taken from the stream (Fig. 2). This high amount of P could be attributed to the rich vegetation cover surrounding the stream and the intact $\mathrm{P}$ in the rock particles which compose the sediments. Debris from rottting plant and animal biomass usuall sink and settle into the bottom of the stream. Degradation and leaching caused primarily by the action of flowing water rapidly follows, allowing the release of $\mathrm{P}$ from these materials The released $\mathrm{P}$ could either accumulate in the area where it sinks or flows with the water downstream. $\mathrm{P}$ from these debris, along with the other sand particles, could altogether add much $\mathrm{P}$ to the sediments. The combined mean total $\mathrm{P}$ of streamwater and stream sediments $(538.40 \mathrm{ppm})$ exceeds the amount of $\mathrm{P}$ which the rain brings into the ecosystem. Obviously, the phosphorus in the geosystem components slowly decreased with time.

\section{Biosystem components}

Data revealed that among the biosystem components, fresh leaves of the dominant vegetation Pterocarpus indicus, Pentacme contorta, Parashorea plicata, and Dracontomelon dao had the highest amount of total P (1847.48 ppm) while the wood from fallen trees had the lowest (216.34 ppm) (Fig.3). It has been suggested that one nutrient conserving mechanism of tropical forest is the storage of nutrients primarily in the biomass where they cannot be leached in contrast to forests in other regions where nutrients are stored in the soil (Richards, 1952).

Live plants must contain high $\mathrm{P}$ concentration for the many physiological processes they perform. Leaves perform most of these processes, hence, it is 


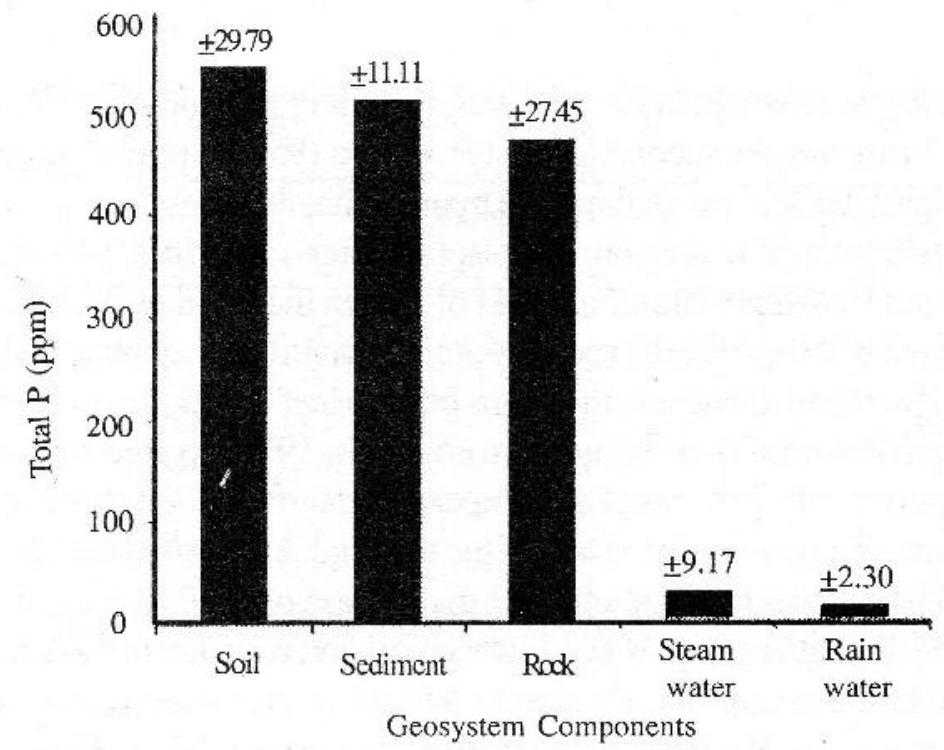

Figure 2. Total $\mathrm{P}(\mathrm{ppm})$ stocks in the geosystem components of the rain forest in Mt. Pangasugan, Baybay, Leyte (values shown on top of the bars are the standard deviation of the means)

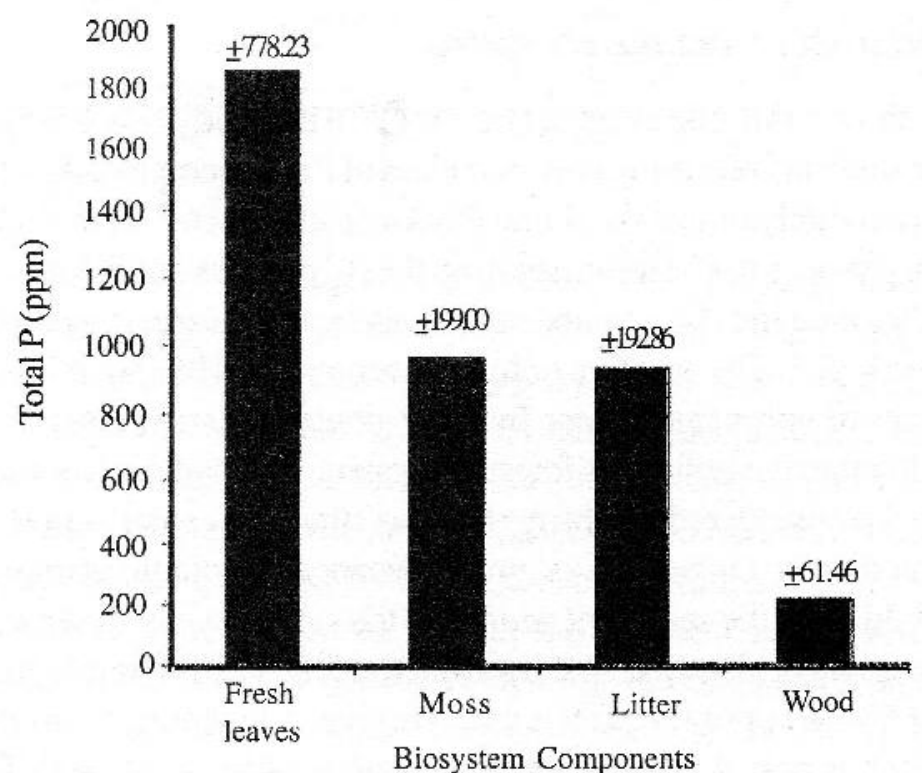

Figure 3. Total P comntents of the biosystem components in the rain forest in Mt. Panagasugan, Baybay, Leyte (values shown on top of the bars are the standard deviation of the means) 
always in the leaves where many nutrients, including $\mathrm{P}$ accumulate (Wang $e t$ al., 1996). Moss had the second highest $P$ content ( 959.84 ppm) suggesting it also accumulates $\mathrm{P}$ in much the same manner that the trees do.

Because mature leaves are sure to fall after sometime, plants have developed mechanisms to minimize loss of $\mathrm{P}$ from their bodies. Robert $e t$ al. (196) observed that $P$ tends to be very low during maximum leaf fall period.This is because $P$ is retranslocated to the stems prior to leaf abscission to conserve and maintain $P$ within their body (Herrera et al., 1978 as cited by Jordan, 1985). Moreover, the process of decomposition starts as soon as leaves fall on the ground and various factors affect the material.Along with the break-up of the plant particles is the disintegration and release of the $P$ it contains. This explains why $P$ in litter samples was lower compared with that in fresh leaves.

Wood had a mean total $P$ value of $216.34 \mathrm{ppm}$, the least among the biosystem components. This suggests that $\mathrm{P}$ accumulates in the actively photosynthesizing organs especially the leaves and less in the stem. In a study in Malaysia, Nykvist (1997) found $4.1 \mathrm{~kg} \mathrm{Pha}^{-1}$ in leaves and $2.5 \mathrm{~kg} \mathrm{Pha}^{-1}$ in dead and more or less decomposed stems and bigger branches.

\section{$P$ stocks and losses from the ecosystem}

Table 1 shows a simple balance sheet for $\mathrm{P}$ in the study site during the conduct of the study in 2003 using only the values of $\mathrm{P}$ concentration. Although this does not accurately reflect the actual $\mathrm{P}$ balance in the ecosystem studied, it nevertheless provides useful information on the $\mathrm{P}$ dynamics and distribution. The $P$ stocks include the $P$ contained in the leaves of the forest vegetation, liter, moss, and wood. The addition or input is represented by $\mathrm{P}$ in rainwater while the losses or output are shown by the $\mathrm{P}$ content in stream water and sediments. Although it is still in the forest ecosystem, much of the P in stream sediments can be considered as a form of P loss since only small amount of this $P$ is returned to the terrestrial system for instance by aquatic animals. In fact, much of this $P$ in the sediment goes with the stream water down to the sea. The balance sheet also clearly shows that the forest ecosystem is losing an average of $538.40 \mathrm{ppm} P$ which is much higher than the input from the rainwater which is only $4.29 \mathrm{ppm}$. The continuous occurrence of shifting cultivation in some portions of the ecosystem is probably the cause for the high $\mathrm{P}$ losses. 
Table 1. Approximate $\mathrm{P}$ balance in the study site in Mt. Pangasugan, during the time of the study in 2003

\begin{tabular}{lcc}
\hline Components & $\begin{array}{c}\text { Amount of P } \\
(\mathrm{ppm})\end{array}$ & Percentage \\
\hline
\end{tabular}

A. P Stocks

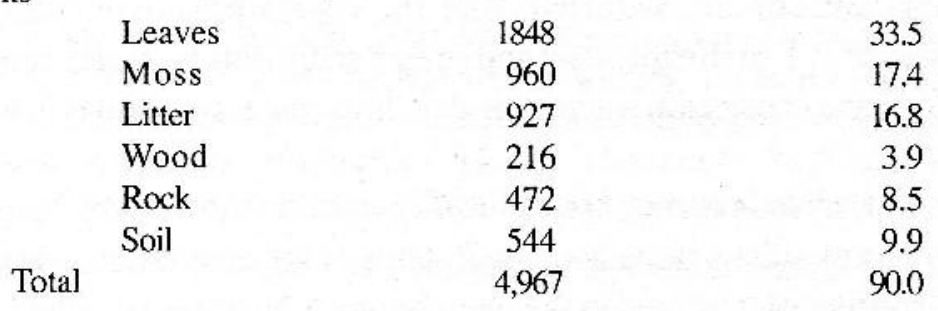

B. Addition (input)

$\begin{array}{lll}\text { Rainwater } & 4 & 0.3\end{array}$

C. Losses (output)

\begin{tabular}{lrrr} 
& Streamwater & 26 & 0.3 \\
& Stream sediments & 512 & 9.3 \\
Total & 538 & 9.8 \\
& & & \\
Net amount & 4,433 & 80.5 \\
\hline
\end{tabular}

\section{Implication of results}

The study revealed great variations in the status and distribution of $\mathrm{P}$ among the geosystem and biosystem components of the forest ecosystem studied. The findings that much of the $\mathrm{P}$ is found in the biosystem component of the ecosystem, with trees having the higher $\mathrm{P}$ concentration tend to support the hypothesis that tropical forests store nutrients in the biomass as a nutrient conserving mechanism (Richards, 1952). On the other hand, it contradicts the the observation of Jordan (1986) that the accumulation of P in the biomass of tropical forest is not important. Despite the fact that $\mathrm{P}$ supply is limited in this ecosystem, plants are still vigorously growing. Decomposition process releases $\mathrm{P}$ to the soil, making it available for plant uptake and nutrient recycling. The fact that considerable proportion of $\mathrm{P}$ is found in the rocks, $\mathrm{P}$ stock is favorable -to the ecosystem in the form of $\mathrm{P}$ in rainwater. However, much $\mathrm{P}$ is lost from 
the soil through run-off and probably to a lesser extent leaching water. Unfortunately, the amount of P lost from the ecosystem (as indicated in the total $\mathrm{P}$ in stream water and in sediments) is considerably higher compared with the P input coming from the rain.

The study implies that cutting and burning of the forest and other associated plants or any disturbance of the vegetation cover could cause heavy losses of P. P in stream water and stream sediments indicates continuing P losses from the ecosystem suggesting that the forest ecosystem is losing its $\mathrm{P}$ stock.

The widespread practice of slash-and-burn cultivation in Mt. Pangasugan could have tremendous impact on the P status of the ecosystem. Most of the $\mathrm{P}$ and other mineral nutrients in the plant biomass become ash after burning much of which are lost in the run-off water.

\section{CONCLUSIONS}

The concentration of phosphorus varied greatly in the various ecosystem components evaluated. Higher P concentrations were observed in the biosystem components particularly in the leaves of trees. In terms of $\mathrm{P}$ concentrations the following order was observed: leaves $>$ moss and moss-like plants $>$ litter $>$ soil $>$ sediment $>$ rock $>$ wood $>$ streamwater $>$ rainwater. Rainwater brings the only outside addition or input of $\mathrm{P}$ into the forest ecosystem. This is much lower than the losses or output represented by $\mathrm{P}$ in streamwater and stream sediments. Thus, the forest ecosystem is losing considerable amounts of $\mathrm{P}$.

\section{ACKNOWLEDGMENT}

The authors are grateful to Dr. Beatriz S. Belonias and Prof. Senona Cesar of the Department of Biological Science at Leyte State University for their comments and suggestions on the thesis manuscript on which this paper was based. We also thank the two referees for their constructive comments on the paper. 


\section{LITERATURE CITED}

ASIO, V. B. 1996. Characteristics, Weathering, Formation and Degradation of Soils from Volcanic Rocks in Leyte, Philippines. Hohenheimer Bodenkundliche Hefte 33. Stuttgart. $209 \mathrm{pp}$.

ASIO, V. B. and M. J. M. BANDE. 2005. Innovative community-led sustainable forest reserve conservation and management in Baybay, Leyte, the Philippines. In: Innovative Communities: People-centered approaches to environmental management in the Asia-Pacific Region (J. Velasquez, M. Yashiro, S. Yoshimura and I. Ono, ed.) United Nations Univ. Press Tokyo-New York-Paris. pp. 204-224.

ASIO, V. B,, R. Jahn, K. Stahr, and J. Margraf. 1998. Soils of tropical forest of Leyte, Philippines. In: Soil of Tropical Forest Ecosystem. (A. Schulte and D. Ruhiyat, eds.) Springer Verlag, Berlin-Heidelberg, New York. pp.37-44.

DAY, L. D., M. E. COLLINS, and N. E. WASHER. 1987. Landscape position and particlesize effects on soil phosphorus distributions. Soil Sci. Soc. Am. J. 51:1547-15.

JORDAN, C. 1985. Nutrient Cycling in the Tropical Forest Ecosystems. John Wiley and Sons Ltd. Chichester. $189 \mathrm{pp}$.

KUO, S. 1996. Phosphorus. In: Methods of Soil Chemical Analysis (Sparks, D., ed.). Soil Sci. Soc. of America, Madison, Wisconsin, USA. pp.869-872.

MARSCHNER, H. 1995. Mineral of Higher Plants. (2nd ed.). Academic Press, Cambridge. $889 \mathrm{pp}$.

NYKVIST, N. 1997. Total distribution of plant nutrients in a tropical rainforest ecosystem. Sabbah, Malaysia. Ambio. 26:152-157.

PCARR. 1980. Standard Methods of Analysis for Soils, Plant Tissues, Water, and Fertilizer. Los Baños, Laguna. 194 pp.

RICHARDS, P. W. 1952. The Tropical Rain Forest. (2nd ed.) Cambridge University PressCambridge.

ROBERT, B., A. CARITAT, O. BERTONI, L. VILAR, and M. MOLINAS. 1996. Nutrient content and seasonal fluctuations in the leaf component of Cork-oak (Quercus suber L) litterfall. Vegetation. 122-29-35.

SANCHEZ, P. 1976. Properties and Management of Soils in the Tropics. John Wiley and Sons, Inc. New York. 618 pp.

SCHLICHTING, E., H. P. BLUME, and K. STAHR. 1995. Soil Science Practicum. (2nd ed). Blackwell, Bêrlin. 295 pp. 
VITOUSEK, P. 1994. Litterfall, nutrient cycling, and nutrient limitation in tropical rain forests. Ecology. 65:285-98.

WANG, J. R., A. L. ZHONG, S. W. SINARD and J. P. KIMMINS. 1996. Aboveground biomass and nutrient accumulation in an age sequence of paper birch (Betula papyrifera) in the interior cedar humlock zone, British Columbia. Forest Ecol. and Management. 83:27-38.

WEDEPOHL, K. H. 1969. Handbook of Geochemistry. Vol. 1. Springer-Verlag, Berlin. pp.227-249.

ZIKELI, S., V. B. ASIO, and R. JAHN 2000. Nutrient status of soils in rainforest of Mt. Pangasugan, Leyte, Philippines. Ann Trop. Res. 22(1\&2):40-78. 